\title{
Investigation of Bond Strength Between GFRP Wrapped Steel Reinforcement and Concrete with Pullout Test
}

\author{
Bogachan Basaran' ${ }^{1}$ Erkan Turkmen Donmez ${ }^{2}$ (D) \\ ${ }^{1}$ Amasya University, Department of Construction, Amasya, Turkey \\ ${ }^{2}$ Amasya University, Department of Design, Amasya, Turkey
}

\section{ABSTRACT}

$\mathrm{T}$ he bond behavior of glass fiber reinforced plastic (GFRP) wrapped deformed steel re1 inforcements having corrosion resistant with concrete is one of the important factors affecting the flexural performance and ductility of structural member exposed to bending. However, the number of studies on the bond of these reinforcements with concrete is insufficient due to not existing so much investigation on this issue. In this study, resin-impregnated glass fibers were wrapped on deformed steel reinforcements and new composite reinforcements of three diameters were produced, and these composite reinforcements bond with concrete were examined by pullout test. In addition, the bond of these composite reinforcements was compared with the bond of unwrapped deformed steel reinforcement. In this context, a total of 18 pullout tests were conducted in the study. As a result of the study, it is observed that maximum bond strength of FRP wrapped deformed steel reinforcements being not applicated surface deformation (ribs, wound, sand coated etc.) ranged from 0.41 times to 0.64 times according to unwrapped steel reinforcements. In addition, it has been observed that the GFRP wrapped steel reinforcements maintain their bond strength up to high slipping values after reached the maximum bond strength values, compared to unwrapped deformed steel reinforcements.

\author{
Article History: \\ Received: 2020/08/21 \\ Accepted: $2020 / 11 / 28$ \\ Online: 2020/12/31 \\ Correspondence to: Boğaçhan Başaran, \\ E-mail:bogachan.basaran@amasya.edu.tri \\ Phone: +903582115042 ; \\ Fax: +903582180104 .
}

Keywords: Bond strength, Hybrid FRP reinforcement, Bond of reinforcement, GFRP reinforcement, Composite rebar, Technical textiles, Glass fiber.

\section{INTRODUCTION}

$D^{1}$ ue to the corrosion of steel in reinforced concrete structures over time, the use of corrosion-resistant glass fiber reinforced polymer (GFRP) reinforcements as reinforcing bars in concrete has become increasingly common in recent years. Production costs are decreasing due to the widespread use of GFRP and their usage areas are increasing. However, since GFRP reinforcements have low shear and compressive strength (310-482 $\mathrm{MPa})$ compared to tensile strengths (450-1600 MPa), FRP reinforcement usage as reinforcement bars in concrete is limited. For this reason, GFRP reinforcements are generally used as tension bars or stirrups in flexural members like such as beams and slabs. In addition, GFRP reinforcements reduce the ductility of structural members and cause them to have a brittle structural behavior due to their brittle stress-strain behavior (rupture strain 1.2-5\% and linear behavior until rupture) compared to steel reinforcement (1-3).
Researchers have developed two different methods to overcome the disadvantages of GFRP and steel materials used in the structural member compared to each other. One of these methods is to use both FRP reinforcements and steel reinforcements independently from each other in the same structural member. In this method, it is aimed to reduce the displacement problems that occur under the usage load of FRP reinforced beams depending on the use of steel reinforcement (4-6). Another method is to produce new composite reinforcements by combining different types of materials (7-15) Composite reinforcements produced by this method are generally of two types. One of them can be in the form of wrapping / braiding / pultrused GFRP around a deformed / plain steel core. Other one can be on the basis of the use of distributed steel wires in the GFRP reinforcement. The production purposes of these reinforcements can be listed as follows; to protect the steel from corrosion by covering around the steel with FRP; to increase the low elasticity modulus of GFRP (35-60 
GPa) by using steel in reinforcement; to eliminate the brittle stress-strain behavior of GFRP; to reduce the cost of GFRP.

As it is known, bond behavior between reinforcement and concrete affects significantly the flexural capacity and ductility of the structural members and can determine the energy absorbing capacity of the structural members. Determine the bond strength between the reinforcement bars and concrete is affected by many factors like type of reinforcement, reinforcement surface properties, reinforcement diameter, reinforcement embedment length, concrete compressive strength, etc. For this reason, it has been observed that the bond strength of GFRP reinforcements with concrete varies between 0.34 and 1.28 times the bond strength of steel reinforcements (16). However, since the number of studies conducted in the literature on these reinforcements is very limited, the number of resources related to bond between concrete and GFRP+steel reinforcement is very low. Ju, et al. (17), produced composite reinforcements by braiding glass fiber impregnated with vinylester on ribbed steel reinforcements. In addition, on these reinforcements have been applied various surface deformations (rib spacing, sandcoated shape). In the study, the effect of surface deformation properties of these reinforcements on bond behavior was investigated with 30 pullout tests. As a result of the study, it was observed that the bond strength of the completely sanded reinforcements had the highest bond strength (approximately $90.5 \%$ of the steel reinforcement, $20 \mathrm{MPa}$ ). Saikia et al. (18) produced composite reinforcements by helically wrapping the epoxy impregnated glass fiber strands on the plain steel core. The bond strength is $3.3 \mathrm{MPa}$ as a result of the pullout test. In addition, it was stated that the beams constructed by using these reinforcements had collapsed due to lack of bond in beams.

In this study, new composite reinforcement have been produced by wrapped resin-impregnated glass fibers on the deformed steel reinforcement with the filament winding method. Wrapped reinforcements produced with this production method have much higher ductility (approximately 3 times higher) unlike the hybrid reinforcements produced in previous studies $(17,18)$ (strain values at maximum stress approximately $1.5 \%$ ). For this reason, the bond behavior of composite (steel+GFRP) reinforcements with this high ductility has not been studied before. Therefore, the bond behavior of these reinforcements should be examined. In the study, the effect of the reinforcement diameter and the GFRP ratio on the bond strengths and behaviors of the produced reinforcements with concrete were investigated with nine pullout tests. In addition, bond behaviors of concrete with unwrapped deformed steel reinforcement $(8,10$ and 12 $\mathrm{mm}$ ) composed of the core part in GFRP wrapped reinforcement were investigated with nine pullout tests. As a result of the study, the bond behaviors of the two reinforcement types were compared.

\section{EXPERIMENTAL STUDY}

\section{Production of GFRP Wrapped Steel Reinforcements}

Within the scope of the study, filament winding method was used to produce glass reinforced plastic (GFRP) wrapped steel reinforcements (Fig. 1). This method is generally used in composite pipe production (19-21). The production of reinforcements was carried out in three stages. In the first stage, $0.9 \mathrm{~mm}$ diameter glass fiber were passed through the epoxy resin bath and epoxy was absorbed into the glass fiber. In the second stage, epoxyimpregnated glass fibers are winding on deformed steel reinforcements of various diameters $(8,10$ and $12 \mathrm{~mm})$ rotating at a constant speed, at an angle of 30 degrees to increase the reinforcement ductility in two layers. In the third stage, steel reinforcements wrapped GFRP were cured after 2 hours of $80^{\circ} \mathrm{C}$ and then cured again for 2 hours at $120^{\circ} \mathrm{C}$.

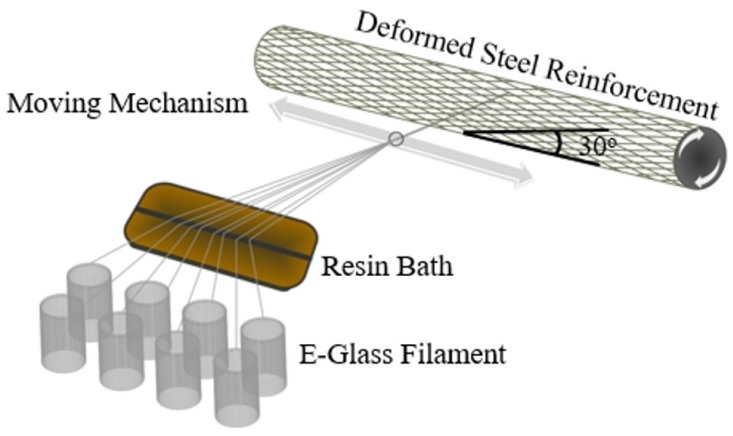

Figure 1. Production of GFRP wrapped steel reinforcements

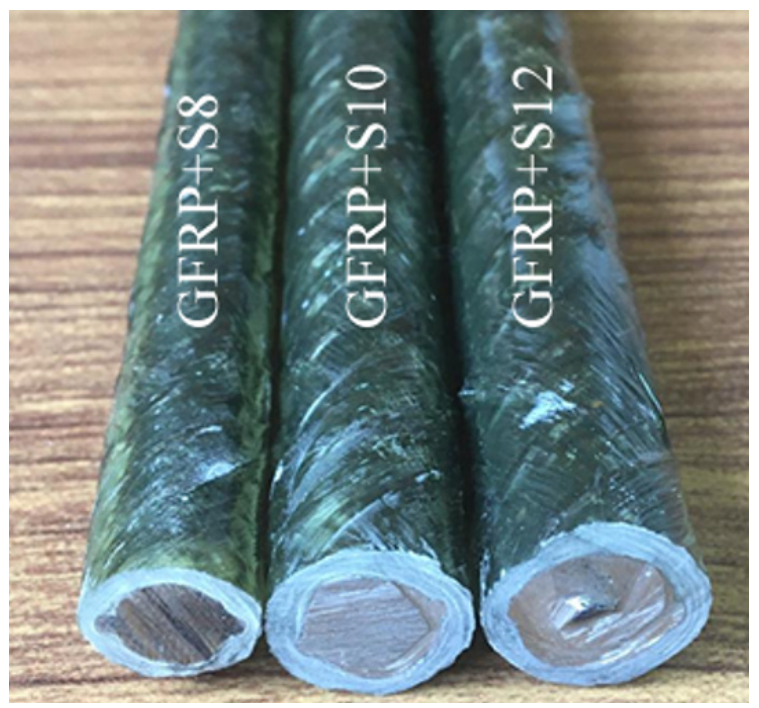

Figure 2. Production of completed reinforcement 
Table 1. Physical and mechanical properties of fibers and resin.

\begin{tabular}{ccc}
\hline & E-Glass fiber & Epoxy \\
\hline Filament tex $(\mathrm{g} / \mathrm{1000 \textrm {m } )}$ & 2501 & - \\
Filament diameter $(\mu \mathrm{m})$ & 17.8 & - \\
Density $\left(\mathrm{g} / \mathrm{cm}^{3}\right)$ & 2.6 & 1.18 \\
Tensile strength $(\mathrm{MPa})$ & $3300-3900$ & 61 \\
Tensile elongation $(\%)$ & $4.5-4.9$ & 2 \\
Modulus of elasticity $(\mathrm{GPa})$ & $78-80$ & 3.64 \\
\hline
\end{tabular}

The physical and mechanical properties of glass fibers and epoxy resin, which are the materials that make up the FRP wrapped ribbed steel reinforcement, are shown in Table 1 and the reinforcements produced are shown in Fig. 2. The values of glass fibers and epoxy resin have been obtained from the manufacturer's catalog data.

\section{Mechanical and Physical Properties of Reinforcements}

In order to determine the tensile properties of the reinforcements produced by wrapping two layers of GFRP with a thickness of $0.9 \mathrm{~mm}$ on the 8,10 and $12 \mathrm{~mm}$ deformed steel reinforcement used in the study and the steel properties of the steel reinforcement, a total of 18 tensile tests were performed. Tensile tests of steel reinforcement have been done according to EN ISO 15630-1 (22) and EN ISO 6892-1 (23) standards. Tensile tests of GFRP wrapped steel reinforcement were carried out by making caps similar to the tensile caps specified in ASTM D 7205 (24). The physical and mechanical properties of the reinforcements are presented in Table 2. In Table 2, $D_{\text {steel }}$ is the outer diameter of the ribbed steel reinforcement $(\mathrm{mm})$; $D$ is the outer diameter of GFRP wrapped deformed steel reinforcement $(\mathrm{mm}) ; n=A_{G F R P} / A$ is the ratio of the GFRP cross-sectional area to the entire reinforcement in the GFRP wrapped deformed steel reinforcement. $\sigma_{\text {yield }}$ , $0.2 \%$ is the average yield strength of the reinforcement, corresponding to $0.2 \%$ elongation percentage from the origin in the stress strain diagram $(\mathrm{MPa}) ; \sigma_{\text {ultimate }}$ is the average maximum tensile strength of the reinforcement $(\mathrm{MPa}) ; \varepsilon_{\text {max }}$ is the strain that corresponds to the ultimate stress (\%); $E_{0.2 \%}$ is the slope of the line drawn from origin onto the stress value corresponding to the percent elongation of $0.2 \%$ in the stress strain diagram (GPa). In the determination of the reinforcement yield stress in the stress-strain diagrams of the hybrid reinforcement, the $0.2 \%$ offset method was not used, since the hybrid rein forcement exhibits a parabolic behavior up to the yield zone (the beginning of the 2nd linear line) (Fig. 3). While determining the yield stresses of the reinforcement, instead of this method, the stress values corresponding to the $0.2 \%$ strain value from the origin (because of the reinforcement yielding at the end of the parabolic curve) has been used.

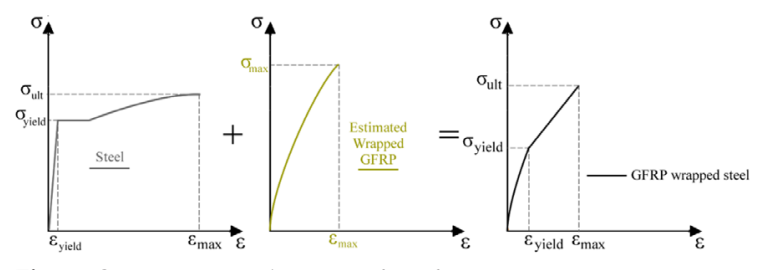

Figure 3. Stress-strain diagrams of reinforcements.

Table 2. Physical and mechanical properties of reinforcements.

\begin{tabular}{|c|c|c|c|c|c|c|c|}
\hline $\begin{array}{c}\text { Reinforcement } \\
\text { type }\end{array}$ & $\begin{array}{l}D_{\text {steel }} \\
(\mathrm{mm})\end{array}$ & $\begin{array}{c}D \\
(m m)\end{array}$ & $n$ & $\begin{array}{c}\sigma_{\text {yield, } 0.2 \%} \% \\
(\mathrm{MPa})\end{array}$ & $\begin{array}{l}\sigma_{\text {ultimate }} \\
(\mathrm{MPa})\end{array}$ & $\begin{array}{l}\varepsilon_{\max } \\
(\%)\end{array}$ & $\begin{array}{l}E_{0.2 \%} \\
(G P a)\end{array}$ \\
\hline Steel & 8.17 & - & & 465 & 735 & 12.76 & 222 \\
\hline Steel & 10.16 & - & & 426 & 667 & 12.12 & 190 \\
\hline Steel & 12.28 & - & & 440 & 673 & 16.88 & 212 \\
\hline GFRP+ Steel & 8.17 & 11.77 & 0.52 & 226 & 478 & 4.88 & 113 \\
\hline$G F R P+$ Steel & 10.16 & 13.76 & 0.45 & 241 & 541 & 5.78 & 120 \\
\hline GFRP+ Steel & 12.28 & 15.88 & 0.40 & 242 & 528 & 6.44 & 121 \\
\hline
\end{tabular}

\section{Mechanical and Physical Properties of Concrete}

C25 / 30 class concrete having maximum aggregate diameter of $16 \mathrm{~mm}$ is used in the pullout test samples. In addition, CEM I $42.5 \mathrm{~N}$ and Water/Cement ratio of 0.60 were used as cement type in the concrete mixture. Mixture calculations of concrete were made according to TS 802 (25). The materials and their proportions that compose of the concrete mixture are presented in Table 3. In order to determine the concrete compressive strengths, six concrete mixtures prepared in size of 150x150x150 $\mathrm{mm}^{3}$. The 28-day cube concrete compressive strength tests of the samples taken were determined as $30.96 \mathrm{MPa}$ by performing according to TS-EN 12390-3 (26) standard.

Table 3. Mixing ratios of $1 \mathrm{~m}^{3}$ of concrete $\left(\mathrm{kg} / \mathrm{m}^{3}\right)$

\begin{tabular}{ccccc}
\hline $\begin{array}{c}\text { Coarse } \\
\text { aggregate } \\
(5-15 \mathrm{~mm})\end{array}$ & $\begin{array}{c}\text { Fine } \\
\text { aggregate } \\
(0-5 \mathrm{~mm})\end{array}$ & $\begin{array}{c}\text { Water } \\
(\mathrm{kg})\end{array}$ & $\begin{array}{c}\text { Cement } \\
(\mathrm{kg})\end{array}$ & $\begin{array}{c}\text { Density } \\
\left(\mathrm{kg} / \mathrm{m}^{3}\right)\end{array}$ \\
\hline 550 & 1300 & 180 & 300 & 2330 \\
\hline
\end{tabular}

\section{Preparation and Method for Reinforcement Pullout Tests}

While preparing the pull-out test samples, the reinforcements in all samples were adjusted so that the embedment length in the concrete is $5 \Phi(L)$ according to codes ACI 440.3R-12 (27) and ASTM D7913 (28). Thick bands were used to adjust the concrete embedment lengths of the reinforcements. After the prepared reinforcements were centered on 150x150x150 $\mathrm{mm}^{3}$ concrete molds with specially made steel apparatus, the concrete mixtures prepared were casted into the molds. In this way, a total of 9 GFRP wrapped reinforcement pullout test samples were prepared, 3 of each test sample (Fig. 4). In addition, 9 unwrapped steel reinforcement pullout test samples were prepared to compare the bond of FRP wrapped steel re- 
Table 4. Pullout test samples.

\begin{tabular}{ccccc}
$\begin{array}{c}\text { Pullout Test } \\
\text { Sample }\end{array}$ & $\begin{array}{c}D_{\text {steel }} \\
(\mathrm{mm})\end{array}$ & $\begin{array}{c}D \\
(\mathrm{~mm})\end{array}$ & $n$ & $\begin{array}{c}L \\
(\mathrm{~mm})\end{array}$ \\
\hline S8 & 8.17 & - & & 40.85 \\
S10 & 10.16 & - & & 50.80 \\
S12 & 12.28 & - & & 61.40 \\
GFRP+S8 & 8.17 & 11.77 & 0.52 & 58.85 \\
GFRP+S10 & 10.16 & 13.76 & 0.45 & 68.80 \\
GFRP+S12 & 12.28 & 15.88 & 0.40 & 79.40 \\
\hline
\end{tabular}

inforcement samples and unwrapped steel reinforcement samples. The prepared experiment samples are presented in Table 4.

After the experiment samples, which were taken out of the mold at the end of 2 days, were kept under laboratory conditions for at least 28 days, pullout tests were carried out. In the experiments, the heads of the universal testing machine (UTM) with a capacity of $600 \mathrm{kN}$ was rearranged for pullout experiments and the test speed of the machine was adjusted to be $2 \mathrm{~mm}$ per minute. During the experiments, in order to measure the amount of slipping of the reinforcement from the concrete, two pieces of $0.01 \mathrm{~mm}$ precision linear potentiometers were attached to the loading end of the test samples. In addition, during the experiments, voltage changes in both the potentiometers and the load cell of the UTM were recorded with a 16bit high resolution data acquisition system. The image of the test setup and test samples is presented in Fig. 5.

\section{Determination of Bond Strength}

The reinforcement tensile force values obtained for each pullout sample were converted into bond force values using Eq. (1). Eq. (3) is calculated from the tensile force coming to the reinforcement and bond force equation

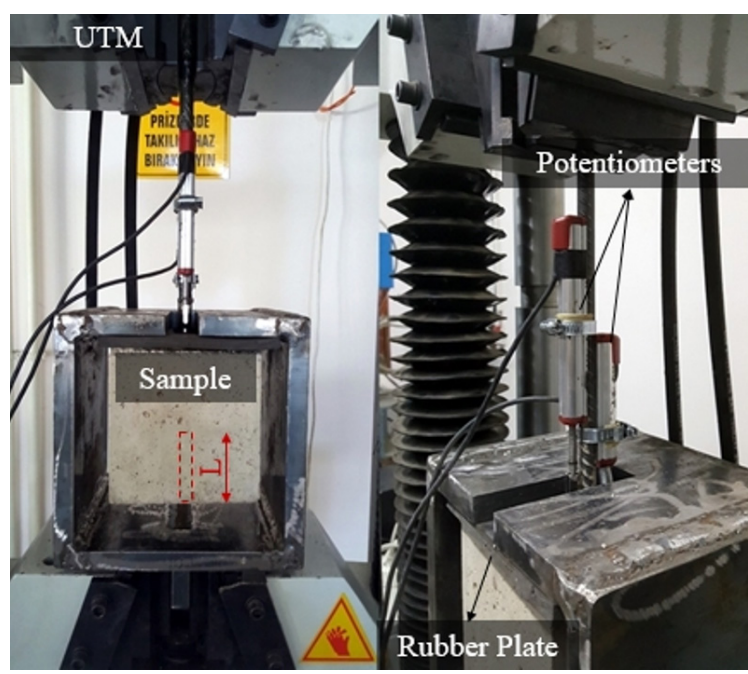

Figure 5. The experimental setup between reinforcement and concrete. In Eq. (3), it is assumed that bond strength are spread homogeneously over the length of bond. Equation 3 is also used in determining the FRP reinforcement-concrete bond strength (28).

$$
\begin{aligned}
& F_{\text {tensile }}=F_{\text {bond }} \\
& F_{\text {tensile }}=\pi D L u \\
& u=\frac{F_{\text {tensile }}}{\pi D L}
\end{aligned}
$$

Where, $F_{\text {tensile }}$ is the pullout force to the reinforcement $(\mathrm{N}) ; F_{\text {bond }}$ is the bond force between reinforcement and concrete $(\mathrm{N}) ; D$ is outer diameter of reinforcement $(\mathrm{mm}) ; L$ is bond length ( $\mathrm{mm}) ; u$ is bond strength between concrete and reinforcement $(\mathrm{MPa})$.

\section{TEST RESULTS}

In this study, 18 pullout tests were carried out to examine the bond between GFRP wrapped steel reinforcement and the unwrapped steel reinforcement with concrete.

\begin{tabular}{|c|c|c|c|c|c|c|}
\hline Test Sample & $\begin{array}{c}D \\
(m m)\end{array}$ & $\begin{array}{c}L \\
(\mathrm{~mm})\end{array}$ & $\begin{array}{l}F_{\max } \\
(N)\end{array}$ & $\begin{array}{c}U_{\max } \\
(M P a)\end{array}$ & $\begin{array}{l}U_{\text {average }} \\
(\mathrm{MPa})\end{array}$ & Failure Mode \\
\hline S8-1 & 8.17 & 40.9 & 25007 & 23.85 & & Pullout \\
\hline S8-2 & 8.17 & 40.9 & 27912 & 26.62 & 25.10 & Pullout \\
\hline S8-3 & 8.17 & 40.9 & 26043 & 24.84 & & Pullout \\
\hline $\mathrm{S}_{10-1}$ & 10.16 & 50.8 & 32992 & 20.35 & & Pullout \\
\hline $\mathrm{S}_{10-2}$ & 10.16 & 50.8 & 38827 & 23.95 & 22.51 & Pullout \\
\hline $\mathrm{S}_{10-3}$ & 10.16 & 50.8 & 37681 & 23.24 & & Pullout \\
\hline$S_{12-1}$ & 12.28 & 61.4 & 48080 & 20.30 & & Pullout \\
\hline$S_{12-2}$ & 12.28 & 61.4 & 48894 & 20.64 & 20.74 & Pullout \\
\hline$S_{12-3}$ & 12.28 & 61.4 & 50438 & 21.29 & & Splitting \\
\hline$G F R P+S 8-1$ & 11.77 & 58.9 & 23814 & 10.94 & & Pullout \\
\hline$G F R P+S 8-2$ & 11.77 & 58.9 & 21088 & 9.69 & 10.37 & Pullout \\
\hline$G F R P+S 8-3$ & 11.77 & 58.9 & 22786 & 10.47 & & Pullout \\
\hline$G F R P+S_{10-1}$ & 13.76 & 68.8 & 29061 & 9.77 & & Pullout \\
\hline$G F R P+S 10-2$ & 13.76 & 68.8 & 32553 & 10.95 & 10.84 & Pullout \\
\hline$G F R P+S 10-3$ & 13.76 & 68.8 & 35066 & 11.79 & & Pullout \\
\hline$G F R P+S_{12-1}$ & 15.88 & 79.4 & 55567 & 14.03 & & Splitting \\
\hline$G F R P+S 12-2$ & 15.88 & $79 \cdot 4$ & 53333 & 13.46 & 13.26 & Splitting \\
\hline$G F R P+S_{12-3}$ & 15.88 & 79.4 & 48659 & 12.28 & & Pullout \\
\hline
\end{tabular}
The pullout test results are presented in Table 5.

Table 4. Pullout test samples.

Various error modes can occur during pullout tests (reinforcement failure, pull-out failure, concrete splitting failure, concrete cone failure) (29-30). In this study, generally, 
pullout and splitting failures were observed. However, due to the short embedment length of the reinforcement $(5 \Phi)$ in the concrete, the number of experiments that resulted in pullout failure was observed are considerably higher than the number of experiments that resulted in splitting failure mode. General pullout samples of GFRP wrapped reinforcement and deformed steel reinforcement that resulted in pullout failure mode are presented in Figures 6.a and 6.b, respectively. No visible deformation was observed on the surfaces of GFRP wrapped reinforcements pullout from concrete. The experiments that resulted in the splitting of concrete were generally seen in samples with large reinforcement diameters. The reason is that may be the high bond forces. As the bond force carried by mechanical locking increases, the radial forces occurring perpendicular to the reinforcement axis increase and therefore the concrete is split by exceeding the tensile strength of the concrete. Some of the test samples that resulted in splitting failure mode are presented in Fig. 6.c-e.

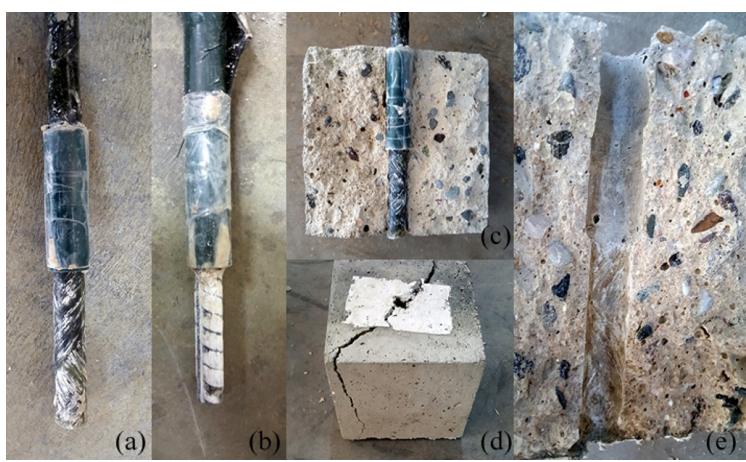

Figure 6. Samples of collapse after the experiments

The average bond strength of reinforcements produced by wrapping GFRP on $8 \mathrm{~mm}$ diameter deformed steel reinforcements are 0.41 times the average bond strength of 8 $\mathrm{mm}$ diameter unwrapped steel reinforcements. This ratio is 0.48 for $10 \mathrm{~mm}$ reinforcement and 0.64 for $12 \mathrm{~mm}$ reinforcement (Fig. 7). However, although GFRP wrapped deformed reinforcements are not subjected to any surface deformation (rib, groove, sand coated, etc.), bond strength values with concrete are quite satisfactory. As it can be seen from Fig. 7, steel reinforcement diameter increases while reinforcement bond strength decreases. However, bond strength increases in FRP wrapped reinforcements.

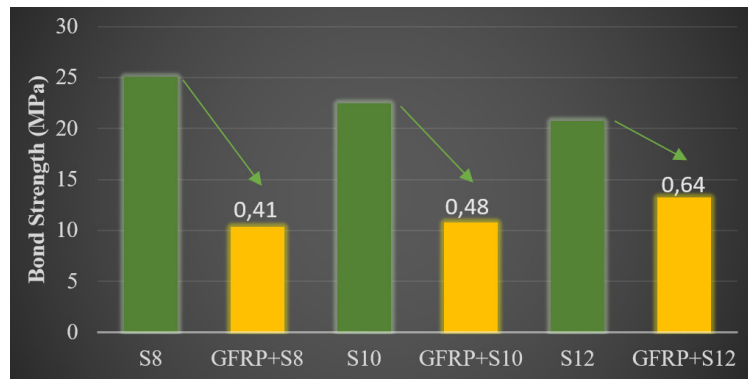

Figure 7. Comparison of average bond strength of reinforcements
In Fig.8, the relationship between the bond strength of the reinforcement with concrete and the GFRP section ratio in the reinforcement section is shown. There is a very high correlation between these two factors, such as 0.94 . As can be seen from Fig.8, as the GFRP section ratio in the reinforcement increases, the bond strength between the reinforcement and the concrete decreases.

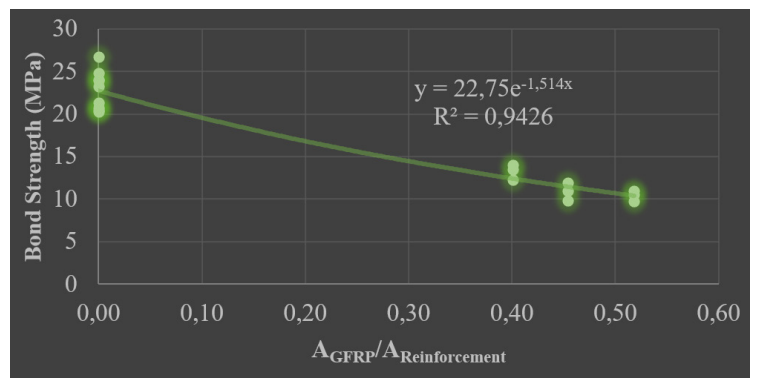

Figure 8. Relationship between bond strength and GFRP crosssectional area

The bond strength-slip curves obtained as a result of pullout tests are presented in Figs. 9, 10 and 11 for both GFRP wrapped and unwrapped deformed steel reinforcements. When the bond strength-slip curves of the reinforcements are examined and it is seen that all GFRP wrapped reinforcements have lower bond stiffness (the slope of the linear line drawn from the origin to the stress value up to point where curve begins) compared to the steel reinforcements. However, the slip values corresponding to the maximum bond strength values of GFRP wrapped reinforcements are very similar to those of steel reinforcements. The difference between the bond stiffness of the reinforcements resulted from the low maximum bond strength of the GFRP wrapped reinforcements compared to the deformed steel reinforcements. In addition, it was observed that bond stiffness decreased with increasing GFRP cross-sectional area. This situation is thought to be caused by the increase in the crushing amount of the GFRP wrapping due to the increase in the GFRP cross section area in the reinforcement.

When the slipping behaviors of the reinforcements after the maximum bond strength are examined, the bond strength values of deformed steel reinforcements have decreased rapidly due to the fact that the ribs of the steel reinforcement shear the concrete suddenly. However, compared to steel reinforcements, GFRP wrapped reinforcements have preserved bond strength values to long slip values by the effect of friction forces. This is thought to be due to the fact that the reinforcement surface is gradually crushed by concrete due to its low rigidity and hardness compared to steel reinforcement. However, it is not clear whether the bond strength values of the reinforcement after the maximum bond strength values are affected by the GFRP crosssectional area in the reinforcement. 


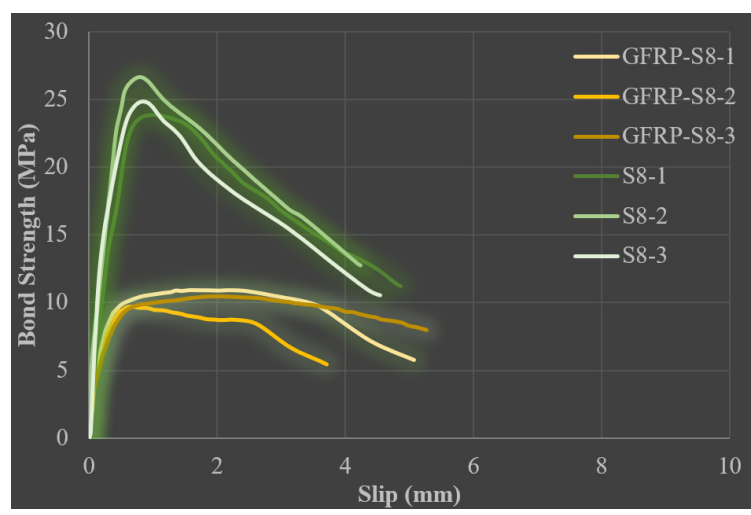

Figure 9. Bond strength-slip curves of $8 \mathrm{~mm}$ reinforcements

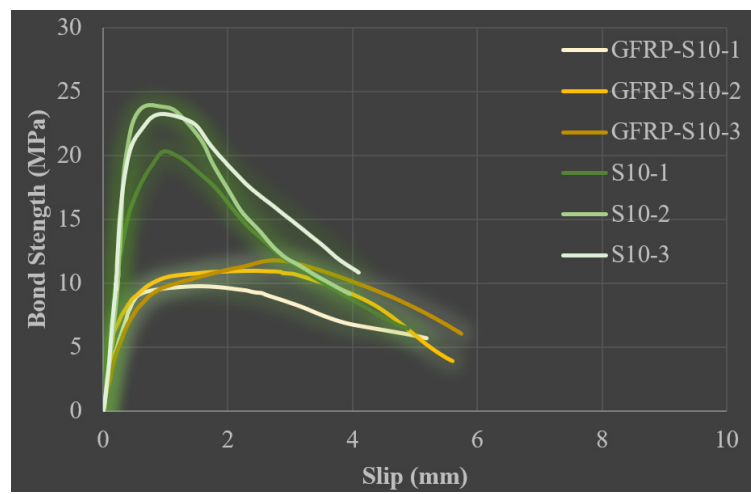

Figure 10. Bond strength-slip curves of $10 \mathrm{~mm}$ reinforcements

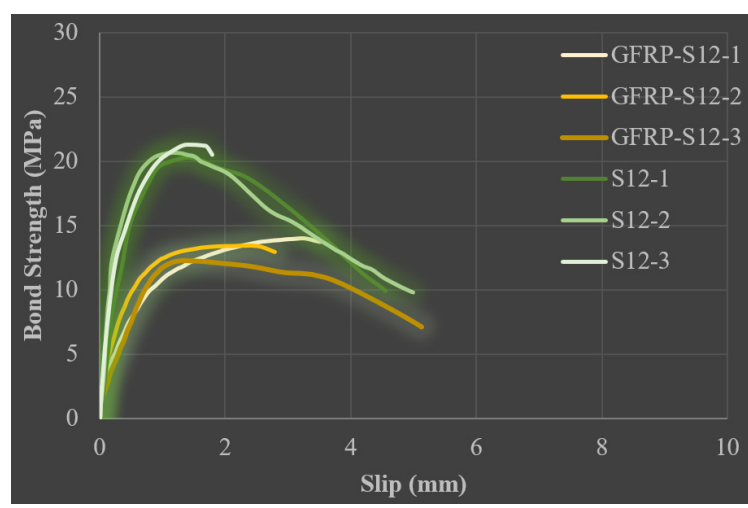

Figure 11. Bond strength-slip curves of $12 \mathrm{~mm}$ reinforcements

\section{CONCLUSIONS}

In this study, the bond behaviors of glass fiber reinforced plastic (GFRP) wrapped steel reinforcements of various diameters produced by filament winding method have been investigated by pullout tests. In addition, bond behavior of deformed steel reinforcements used in making GFRP wrapped reinforcement was also tested under the same experimental conditions. Within the scope of the study, a total of 18 pullout tests were carried out using reinforcements of various diameters embedded in C25 class 150x150x150 $\mathrm{mm}^{3}$ concretes with embedment length of
$5 \Phi$. The main observed developments in the study can be summarized as follows:

- Maximum bond strength of GFRP wrapped deformed steel reinforcements ranged from 0.41 times to 0.64 times the maximum bond strength of steel reinforcement. Although no surface deformation (ribs, grooves, windings, sandblasting, etc.) is applied to the surfaces of GFRP wrapped reinforcements, bond strength of composite reinforcement was seen higher than expected. If surface deformation processes are applied to composite reinforcement, bond strength values can be much more improved.

- Unlike deformed steel reinforcements, bond strength has increased as the reinforcement diameter increases in GFRP wrapped reinforcement. However, this increase was inversely related to the GFRP cross section ratio in GFRP wrapped reinforcements. In addition, due to the increase of the GFRP cross-sectional area in the GFRPwrapped reinforcements, the crushing amount of the GFRP wrapped increases and it has been observed that it has a bond reducing effect.

- $\quad$ The slipping values corresponding to the approximate maximum bond strength of GFRP wrapped reinforcements are similar to those of steel reinforcements.

- $\quad$ Unlike steel reinforcements, bond did not drop suddenly after maximum bond strength in GFRP wrapped reinforcements. Relatively compared to steel reinforcement samples, GFRP wrapped reinforcements maintained their bond strength values up to large slip values.

- $\quad$ At the end of the experiments, due to the short embedment lengths, pullout failure was observed. No visible deformation was observed on the reinforcement surfaces of all samples with GFRP wrapped reinforcement.

As a result, considering that the bond strength values of FRP rebars are in a wide range of 0.34 to 1.28 times the bond strength values of steel rebars, it is thought that additional studies are needed to expand the scope of experimental and statistical studies to determine the bond strength of FRP wrapped reinforcements.

\section{ACKNOWLEDGEMENT}

The study was supported by Amasya University Scientific Research Project Coordination Unit under the project number FMB-BAP 19-0429. This support is gratefully acknowledged. The experiments were conducted in the Structural Material Laboratory of the Technical Sciences Vocational School, Amasya University. 


\section{References}

1. $\mathrm{ACl} 440.1 \mathrm{R}-15$ Guide for the Design and Construction of Structural Concrete Reinforced with Fiber-Reinforced Polymer (FRP) Bars. American Concrete Institute (ACl). MI, USA, 2015.

2. ACl 440R-96 State-of-the-Art Report on Fiber Reinforced Plastic (FRP) Reinforcement for Concrete Structures. American Concrete Institute (ACI). MI, USA, 2002.

3. fib bulletin 40 FRP Reinforcement in RC structures. International Federation for Structural Concrete (fib). Lausanne, Switzerland, 2007.

4. El Refai A, Abed F, Al-Rahmani A. Structural performance and serviceability of concrete beams reinforced with hybrid (GFRP and steel) bars. Construction and Building Materials 96 (2015) 518-29.

5. Lau D, Pam HJ. Experimental study of hybrid FRP reinforced concrete beams. Engineering Structures 32 (12) (2010) 3857-65.

6. Gemi L, Madenci E, Özkılıç YO. Çelik, Cam FRP ve Hibrit Donatılı Betonarme Kirişlerin Eğilme Performansının Incelenmesi. Düzce Üniversitesi Bilim ve Teknol Dergisi 30;8 (2020) 1470-83.

7. Ju M, Lee S, Park C. Response of Glass Fiber Reinforced Polymer (GFRP)-Steel Hybrid Reinforcing Bar in Uniaxial Tension. International Journal of Concrete Structures and Materials 11 (2017) 677-86.

8. Correia L, Cunha F, Mota C, Fangueiro R, Nunes JP. PseudoDuctile Braided Composite Rods (BCRs) Produced by Braidtrusion. In: ECCM17 - 17th European Conference on Composite Materials. Munich, Germany, 2016.

9. Seo D-W, Park K-T, You Y-J, Lee S-Y. Experimental Investigation for Tensile Performance of GFRP-Steel Hybridized Rebar. Advances in Materials Science and Engineering 2016 (2016) 1-12.

10. Seo D-W, Park K-T, You Y-J, Hwang J-H. Evaluation for Tensile Performance of Recently Developed FRP Hybrid Bars. International Journal of Emerging Technology and Advanced Engineering 4(6) (2014) 631-7.

11. Wu G, Sun ZY, Wu ZS, Luo YB. Mechanical Properties of Steel-FRP Composite Bars (SFCBs) and Performance of SFCB Reinforced Concrete Structures. Advances in Structural Engineering 15(4) (2012) 625-35.

12. Behnam BR. Reliability model for ductile hybrid FRP rebar using randomly dispersed chopped fibers. Wayne State University, Detroit, Michigan, 2012.

13. Etman EE-S. Innovative Hybrid Reinforcement for Flexural Members. Journal of Composites for Construction 15(1) (2011) 2-8.

14. Cheung MMS, Tsang TKC. Behaviour of Concrete Beams Reinforced with Hybrid FRP Composite Rebar. Advances in Structural Engineering 13(1) (2010) 81-93.

15. Cui Y, Cheung MMS, Noruziaan B, Lee S, Tao J. Development of ductile composite reinforcement bars for concrete structures. Materials and Structures 41(9) (2008) 1509-18.

16. Basaran B, Kalkan I. Investigation on variables affecting bond strength between FRP reinforcing bar and concrete by modified hinged beam tests. Composite Structures 242 (2020) 112185.

17. Ju M, Park G, Lee S, Park C. Bond performance of GFRP and deformed steel hybrid bar with sand coating to concrete. Journal of Reinforced Plastics and Composites 36(6) (2017) 464-75.

18. Saikia B, Thomas J, Ramaswamy A, Rao KSN. Performance of hybrid rebars as longitudinal reinforcement in normal strength concrete. Materials and Structures 38 (284) (2005) 857-64.

19. Gemi L, Köklü U, Yazman Ş, Morkavuk S. The effects of stacking sequence on drilling machinability of filament wound hybrid composite pipes: Part-1 mechanical characterization and drilling tests. Composites Part B: Engineering 186 (2020) 107787.

20. Gemi L, Köroğlu MA, Ashour A. Experimental study on compressive behavior and failure analysis of composite concrete confined by glass/epoxy $\pm 55^{\circ}$ filament wound pipes. Composite Structures 187 (2018) 157-68.

21. Peters ST. Composite Filament Winding. ASM International, 2011.

22. EN ISO 15630-1:2010 Steel for the reinforcement and prestressing of concrete - Test methods - Part 1: Reinforcing bars, wire rod and wire (ISO 15630-1:2010). European Committee for Standardization. 2010.

23. EN ISO 6892-1:2016 Metallic materials - Tensile testing - Part 1: Method of test at room temperature (ISO 68921:2016). European Committee for Standardization. 2016.

24. ASTM D7205/D7205M-06 Standard Test Method for Tensile Properties of Fiber Reinforced Polymer Matrix Composite Bars. ASTM International. USA, 2016.

25. TS 802 Beton Karışım Tasarımı Hesap Esasları. Türk Standartları Enstitüsü (TSE). Ankara, 2016.

26. EN 12390-3:2009 Testing hardened concrete - Part 3: Compressive strength of test specimens. European Committee for Standardization. 2009.

27. $\mathrm{ACl} 440.3 \mathrm{R}-12$ Guide Test Methods for Fiber- Reinforced Polymer (FRP) Composites for Reinforcing or Strengthening Concrete and Masonry Structures. American Concrete Institute (ACI). MI, USA, 2012.

28. ASTM D7913 / D7913M - 14. Standard Test Method for Bond Strength of Fiber-Reinforced Polymer Matrix Composite Bars to Concrete by Pullout Testing. ASTM International. 2014.

29. $\mathrm{ACl}$ 355.1R-91 State-of-The-Art Report on Anchorage to Concrete. American Concrete Institute (ACI). 1991.

30. Müsevitoğlu A, Arslan MH, Aksoylu C, Özkış A. Experimental and analytical investigation of chemical anchors's behaviour under axial tensile. Measurement 158 (2020) 107689. 